\title{
ABANDONO E ERRÂNCIA: A BUSCA IDENTITÁRIA EM LÉONORA MIANO E PAULINA CHIZIANE
}

\author{
Patrícia Gomes Germano ${ }^{1}$ \\ Rosilda Alves Bezerra²
}

\begin{abstract}
Resumo: O pós-colonial pode ser visualizado como uma condição propícia à mobilidade, à errância, à fluidez. Imersos nesse universo caótico e fraturado, sujeitos vagueiam, pontuam relações e se mobilizam para se afirmarem enquanto identidade em meio aos fluxos, ao nomadismo. Textos timbrados com o "rótulo" de pós-coloniais convidam leitores à reflexão de como itinerários conflituosos, desenvolvidos em espaços de múltiplos encontros, desvelam a fragmentação circunscrita nas formações identitárias. Nesse sentido, a proposta do presente artigo é identificar de que forma esses aportes norteadores de "padrões" e "fixações" identitárias ocorrem nas obras de Léonora Miano e Paulina Chiziane.

Palavras-Chave: Romance pós-colonial, Léonora Miano, Paulina Chiziane.
\end{abstract}

Resumen: Lo postcolonial puede ser visto como una condición que propicia la movilidad, la errancia, la fluidez. Inmersos en este universo de caos y fractura, los sujetos vaguean, crean relaciones y se movilizan por afirmarse en cuanto identidad en medio a los flujos, al nomadismo. Textos caracterizados como postcoloniales invitan lectores a la reflexión acerca de la manera como itinerarios conflictivos, desarrollados en espacios de múltiples encuentros, muestran la fragmentación que ocurre en las formaciones identitárias. EI artículo propone así identificar de que manera estos aportes norteadores de "padrones" y de "fijaciones" identitarias ocurren en las obras de Léonora Miano y Paulina Chiziane.

Palabras-llave: Novela postcolonial, Léonora Miano, Paulina Chiziane.

\section{INTRODUÇÃO}

O pós-colonial (HALL, 2003) pode ser visualizado como uma condição propícia à mobilidade, à errância, à fluidez: palavras que sinalizam às imprevisibilidades (GLISSANT, 2002) inerentes às redes interindividuais ali agenciadas (GUATTARI, 2005) e que, de certo modo, são propulsoras de

1 Doutoranda do Programa de pós-Graduação em Literatura e Interculturalidade, da Universidade Estadual da Paraína (PPGLI/UEPB), Campina Grande. Endereço eletrônico: pa tricia.germano@ig.com.br.

Orientadora. - Professora do Programa de pós-Graduação em Literatura e Interculturalidade, da Universidade Estadual da Paraína (PPGLI/UEPB), Campina Grande. Endereço eletrônico: rosildaalvesuepb@yahoo.com.br. 
complexas cartografias de infâncias, de adolescências, de juventudes, de experiências familiares...

Imersos nesse universo caótico e fraturado, sujeitos vagueiam, pontuam relações e se mobilizam para se afirmarem enquanto identidade em meio aos fluxos, ao nomadismo. Textos timbrados com o "rótulo" de póscoloniais convidam leitores à reflexão de como itinerários conflituosos, desenvolvidos em espaços de múltiplos encontros, desvelam a fragmentação circunscrita nas formações identitárias.

Se pensarmos o pós-colonial como uma condição que, em si, já demanda a instabilidade oriunda daquilo a que Bhabha (1998) chama de "terceiro espaço", há de se esperar que as vivências dos sujeitos, a produção de sua identidade e subjetividade, a relação estabelecida com seus convivas em meio ao rizoma (GUATTARI, 1997), próprio do contexto da pós-colonial, são permeadas por perturbações das antigas verdades, dos aportes norteadores de "padrões" e "fixações" identitárias, bases, outrora, seguras para uma arcaica visão de mundo, abaladas, doravante, pelas desconstruções.

A princípio, compreendemos que o pós-colonial é a condição experimentada por seres e por culturas influenciados pelo processo imperial desde os primórdios da colonização até os dias atuais. Essa "pós-colonialidade" passa a afetar de modo definitivo a vida dos atores envolvidos na dinâmica do colonialismo-pós-colonialismo, posto que as alteridades resultantes deste processo inaugurem a desestabilização de códigos, "afetados" mutuamente, pela diferença entre o mesmo e o diverso (GLISSANT, 2002) num processo de incerteza e imprevisibilidade.

A obra literária, espaço onde o estético desnuda toda sua mensagem criativa, é aqui contemplada como lócus, como território em que essas relações de transformação-transmutação subjetiva-identitária se fazem visualizar, sobretudo em produções que se ocupam do itinerário de personagens imersos em contextos de produção, transformação, escolha identitária.

Partimos do pressuposto de que o texto literário, muito mais que reprodução do real, é produtor de "efeitos de verdade" (FOUCAULT), porque "Só é válido afirmar que o texto literário reproduz a realidade se entendermos que reproduzir significa, literalmente, produzir de novo, ou seja, em um gesto que é, de certo modo, repetição, gerar uma realidade diferente" (SANTOS \& OLIVEIRA, 2001, p. 73).

Por esse enfoque, aproximamo-nos da obra literária oriunda do póscolonial, como esse thopos, cuja estética alia-se à política com escopo de desvendar a violência da colonização e as fraturas ali agenciadas. 
Quando além de tematizar o pós-colonial, com seus estados alterados e identidades reformuladas (APPIAH, 1997), subjetividades cambiantes entre o assujeitamento e a singularização (GUATTARI, 1992), a obra se ocupa em elencar personagens apresentados como "infantes", "adolescentes", "jovens", termos que a própria pós-modernidade põe sob suspeita, a questão identitária se mostra ainda mais problemática, na medida que a "naturalidade" desses agrupamentos vem a ser substituída pela reflexão da historicidade que os tomam como cartografias abertas a uma multiplicidade de entradas.

Quando falamos de identidade, pensamos num recorte que mobilize especificamente, aquelas identificações trilhadas em percursos póscoloniais africanos e que são representadas no texto literário de autoria africana. Partimos das premissas articuladas por Appiah (1997, p. 243), para quem "a identidade humana é construída e histórica [...] fruto de "histórias inventadas, biologias inventadas e afinidades culturais inventadas". Assim, são mais fraturadas, e inacabadas, produto de múltiplas e complexas relações, sempre provisórias, de escolhas e de agenciamentos (GUATTARI, 1992), do que produzidas por aspectos psíquico-cognitivos, ontológicos. Para Appiah (1997, p. 254), "ser africano é, para seus portadores, um dentre muitos outros modelos destacados de ser, por todos os quais é preciso lutar e tornar a batalhar constantemente".

Em consonância a este entendimento, as identificações das etapas de desenvolvimento humano: infância, adolescência, juventude, velhice muito mais do que prerrogativas biológicas, são aqui visualizadas como criações que são produzidas e experimentadas de diferentes formas.

Para Dahllberg; Moss; Pence (2003), tanto a infância quanto a adolescência devem ser compreendidas como categorias formuladas historicamente, ou seja, são resultados de agenciamentos coletivos de enunciação (GUATTARI, 2005) e estão longe de serem imutáveis.

Assim, essas etapas não são experimentadas de forma análoga entre todos os indivíduos de todas as sociedades, como se formulava na visão estrutural da modernidade. O que se observa é a existência de "infâncias" e "adolescências", bem como formas heterogêneas de conviver com elas, de modo que para refletir sobre a produção identitária de seres vistos como crianças e adolescentes africanos em contexto pós-colonial, é necessário perceber as especificidades que essas identificações assumem/assumiram, sobretudo pelo choque que experimentaram/experimentam. 
Assim, propomos pensar sobre as relações familiares desconexas e descontínuas, e a construção identitária do jovem no contexto pós-colonial. Para tanto, tomamos como premissa as mensagens circunscritas nas vivências do sujeito-narrador do romance de Léonora Miano: Contornos do dia que vem vindo (2009) e O alegre canto da perdiz (2010), de Paulina Chiziane.

Pretendemos analisar como a desconstrução da "ordem" familiar tradicional, como o abandono e a errância, tornam-se eixos motivadores da busca identitária desenvolvida pela menina Musango, que transita pela cidade a procura de afirmação, de cidadania, após ser abandonada pela mãe, numa sociedade em que cuidar e educar os filhos torna-se tarefa impossível aos pais. Em O alegre canto da Perdiz (2005), a ação colonial altera o destino de Delfina e Maria das Dores, respectivamente, mãe e filha, que se prostituem em troca de alimento. Esta última é vendida ainda criança, pela própria mãe, ao feiticeiro Simba.

\section{PRELÚDIO, INTERLÚDIO E CODA: CONCERTOS PARA SER...}

O romance Contornos do dia que vem vindo é a segunda narrativa da autora camaronesa radicada na França Léonora Miano, que nasceu em 1973, em Douala, na costa de Camarões. Nesta cidade ela viveu a sua infância e a sua adolescência, antes de partir para a França. A obra em questão legou a autora vários prêmios, foi publicada no Brasil pela Pallas editora em 2009, como homenagem ao ano dedicado à França no Brasil.

O texto narra a história da menina Musango, suas rotas em uma cidade imaginária: Sombê, destroçada pelo embuste colonial e pelas guerras civis do pós-independência. Vale salientar que tanto a cidade de Sombê como o país Mboasu, apresentados como a geografia da obra, são constructos imaginários o que facilita o entendimento de que, a partir dessa produção, Léonora Miano insere o pós-colonial como uma construção, de certo modo, ocidental. Dessa forma, a autora não se limita a especificar nomes ou territórios, talvez na tentativa de sinalizar para as universalizações a que são submetidos os atores e sujeitos da colonialidade.

Na cidade de Sombê, Musango se vê maltrapilha, enfraquecida pela violência familiar, comida pela fome e da perda de identidade. Passa então a desenvolver inúmeros percursos e travessias, vagueia pelas ruas sujas em cuja paisagem cadáveres insepultos de criança servem de pasto aos cães e gatos também abandonados. 
Composto por duzentas e sete páginas, a obra é formulada em cinco conjuntos que fazem referência direta ao campo semântico musical: Prelúdio: ausência (p. 10), Primeiro movimento: volição (p. 35), Interlúdio: resiliência (p. 99), Segundo Movimento: geração (p. 111), Coda: licença (p. 171). Essa escolha da autora já nos sinaliza à compreensão de que a narrativa ali contada possa estar metaforicamente associada a um concerto em que múltiplas interferências, arranjos variados, diversos instrumentos, em que inúmeros regentes vão dando voz, corpo a um todo que se individualiza perante escolhas e interação, consoante aquilo a quem Guattari chama de "paradigma estético", dito de outro modo, a construção subjetiva e, posteriormente, a identitária perpassam o inusitado, o criativo, o imprevisto, abolindo, pois, qualquer ordem ou modelo.

No Prelúdio: ausência, o leitor tem acesso a um universo de reminiscências psicológicas de um narrador cujo nome só é revelado na página vinte e seis:

Há apenas sombras ao redor, é em você que estou pensando. Não que esteja de noite, ou que os vivos tenham de repente adquirido as cores do momento. Poderia ser assim se o tempo ainda se desse ao trabalho de se fracionar em intervalos regulares: segundo minutos, horas, dias, semanas... Mas o próprio tempo se cansou dessa divisão. O tempo, como nós todas, como eu, viu muito bem que tal divisão não fazia sentido. Não aqui onde estamos. Seja manhã ou noite, tudo é parecido. Há apenas sombras ao redor, eu sou uma delas, e é em você que estou pensando. Na última vez que nos vimos, você me amarrou em minha cama. Você me espancou a toda força antes de chamar nossos vizinhos, para que vissem o que você acreditava ter feito com esse espírito mau que vivia sob seu teto e se dizia sua filha (MIANO, 2009, p. 910).

O texto principia com a montagem da identidade de um narradorpersonagem a partir do fornecimento de pequenas peças, como se um quebra-cabeças fosse oferecido ao leitor, com o intuito de que ele estabeleça uma série de possíveis coerências e significações. Primeiramente, percebe-se que se trata de uma pessoa reclusa, trancafiada, pois esta não absorve o sentido de tempo, categoria relativizada na situação em que se encontra: "Mas o próprio tempo se cansou dessa divisão. O tempo, como nós todas, como eu, viu muito bem que tal divisão não fazia sentido. Não aqui onde estamos. Seja manhã ou noite, tudo é parecido" (MIANO, 2009, p. 9).

O fato de o sujeito-narrador está recluso e num ambiente escuro, onde "seja manhã ou noite, tudo é parecido", pode ser associado pelo leitor 
à clausura uterina, e as memórias do narrador, apresentadas no interlúdio, um predecessor do nascimento que ocorrerá no segundo momento do texto. Compreensão ainda ratificada pelo título Contornos do dia que vem vindo, que interliga o dia com nascimento e a expressão, "vem vindo", com o caminho para uma nova vida, um movimento processual. A constatação de que o próprio narrador é um sombra, aponta ainda, para a criação de uma identidade no devir.

Ainda em continuidade a esse interlúdio, a essa "canção" de abertura, o narrador esclarece as condições que a conduziram a esse ambiente de abandono e exclusão. Nas páginas desse capítulo, rememora seu relacionamento conflituoso com a mãe, a expulsão de casa após a morte do pai, a doença que Ihe enfraquece as forças, a associação desta enfermidade a um suposto espírito mau que encarnaria e, por fim, as violências físicas que sofrera antes de ser acusada de feitiçaria e, posteriormente, abandonada pela genitora, aos nove anos de idade e passar a trafegar pelas ruas de Sombê, encorpando a já avantajada legião de crianças abandonadas à própria sorte.

Assim, a narrativa está condensada, num primeiro momento, no abandono que lhe impulsiona a crescer, a buscar significação e construir à própria identidade longe do ambiente familiar. Através das errâncias de Musango, o texto se concentra em observar os percursos desenvolvidos pela menina em busca da mãe, o crescimento interior e a tomada de consciência que ela estabelece em relação à sua identificação num país onde as tradições são reencenadas e as reterritorializações (GUATTARI, 1992) daquilo que veio com o colonizador não garantem melhorias efetivas.

Vale salientar que o contexto pós-colonial, os destroços do país, as perdas dos referenciais vão sendo explorados como forma de se elencar as fraturas e violências ali orquestradas. Um exemplo dessa implosão de valores está na forma como as crianças e adolescentes passam a ser tratados em Mboasu, além de comercializadas ou abandonadas, são alvo de múltiplas formas de violência articuladas pela instabilidade do contexto e legitimadas pelas tradições ancestrais.

Uma vez que não dispõe de apoio por parte do clã do marido morto, Ewenji, mãe de Musango, vê na menina a razão para sua desgraça e desenvolve por ela uma espécie de ódio. Para consumar a violência, recorre à sacralidade ancestral que a aconselha a cometer atrocidades com a criança:

“Ela matou o pai! É por causa dela que ele morreu e que agora nós estamos pobres! Isso me foi revelado e eu preciso me livrar dela..." [...]. Já uma vez você me tinha amarrado na mangueira do quintal e me açoitado até sangrar, 204 Número temático: Literatura, cultura e memória negra. A Cor das Letras - UEFS, n. 12, 2011 
"para extirpar o demônio que ela abriga e que é a causa da nossa desgraça". Alguns dias antes, uma vidente havia confirmado as suas suspeitas a meu respeito. Ela disse: “É a sua menina [...] (MIANO, 2009, p. 11).

É desse modo que as relações familiares, a convivência no contexto pós-colonial está inevitavelmente fraturada pelas interferências sofridas na época da colonização. Os pais não conseguem mais cuidar dos seus filhos, as instituições são e estão esfaceladas. A pobreza, a exclusão, a opressão, advindas da situação de marginalidade são confundidas e explicadas pela ótica das tradições que sobrevivem, e se reterritorializam. Em que se apegar?

Por outro lado, a influência de novos códigos e sentidos perturba essas tradições e lhes determinam novas rotas, como fica claro no caso do "demônio", entidade desconhecida nas cosmogonias africanas e que é acionado pelo pensamento pós-colonial como instrumento de legitimação das atitudes dos pais em relação aos rebentos. Aspectos importantes sobre a formação identitária do africano, a questão da solidariedade clânica, o culto e o apego à ancestralidade, são assim pontuados por Miano.

Conforme Serrano e Waldman (2007, p. 129), "[...] para o africano, a sua identidade está, em primeiro lugar, centrada no núcleo familiar. A família constitui o cerne da vida social no continente [...]". E, a perspectiva de família vai além do núcleo pai-mãe-filho. Notável é a existência de uma "família extensa", um clã responsável pela garantia da saúde emocional, do equilíbrio e da identificação dos seus membros.

Quando Musango é expulsa de casa pela mãe, que no contexto, representa a autoridade e a sabedoria, toda sociedade de Mboasu lhe vira às costas e ela perde a sua identificação primeva construída historicamente pela inserção no grupo familiar, o primeiro laço de formação identitária e desatado restando apenas a incerteza.

Carente de um porto seguro, o sujeito-narrador busca a família paterna como referencial, mas não encontra apoio da avó e nem dos tios, que não ousam acolher a quem a própria mãe desprezou e assim, a menina vaguei pela sarjeta sem merecer a atenção dos passantes, visto que a rotina de violência e maus-tratos contra as crianças se tornara banalidade entre os habitantes de Mboasu que não mais se assombram ou questionam o fato de uma criança surrada, faminta e mal-vestida trafegar pelas ruas. Conforme o texto, não ousam perguntar-Ihes nada, pois "perguntar implica assumir a carga das respostas. Depois, não se pode mais agir como se não sou- 
besse. Ora, naquele tempo ninguém tinha condições para uma tal política" (MIANO, 2009, p. 19).

Se a família, tida pela tradição africana, como a primeira agência de construção histórica da identificação, exime-se dessa responsabilidade, resta ao sujeito-narrador desenvolver novas errâncias em busca dessa arquitetura: a igreja, as autoridades, a escola, aparecem como esses possíveis espaços. No entanto, Musango transita por ele, percebendo-os esfacelados.

Os caminhos de Musango abrem veredas ao leitor da condição caótica da cidade: lixo, miséria, perda de valores e referências: cidadania violentada, exploração... Perambulando pelas vielas de uma feira, Musango é recolhida por Ayanê e Epa para ser conduzida a casa de Aída, uma francesa dedicada a Mboasu, às crianças e adolescentes vitimadas pelas guerras. Mais uma vez, Miano convida o leitor a observar a fragilidade da fixidez identitária, ou mesmo a carência de representatividade do jovem africano que é um nada em meio às mercadorias.

Resgatada após vários dias de silêncio e indiferença, Musango é conduzida a uma casa de caridade e, neste ponto do romance, a partir do diálogo de Ayanê e Aída, tanto o leitor como o sujeito-narrador percebem uma nova configuração para o adolescente do pós-colonial e a relação deles com seus pais, na medida em que os genitores trocam o afeto pela expulsão, doravante motivados pelo próprio instinto de sobrevivência:

Disseram que se chama Musango e que a mãe a expulsou de casa acusando-a de bruxaria. Aída respondeu: Mais uma. [...]. Ao ouvi-las soube que éramos muitos, que com cada vez mais frequência as famílias desprovidas buscavam um pretexto para se desfazer de seus rebentos. O pai perdia o emprego. Depois de alguns dias rondando, afogado numa garrafa de álcool de milho, ele pegava um de seus filhos e o punha para fora. A mãe tinha uma crise nervosa de pensar em enfrentar mais um dia sem saber o que se comeria na casa. De repente, ela descobria que um de seus filhos era decididamente estranho. [...]. Às vezes, os pais iam procurar a aprovação dos espíritos, que sempre concediam, uma vez que eles tinham pagado ao marabu ou dado alguns trocados ao pastor. Os espíritos eram sindicalizados, e sua convenção coletiva resumia-se a algumas palavras: pague antes de ser atendido (MIANO, 2009, p. 23).

Assim, Musango deixa de ser acolhida na família e passa a ser assistida por uma instituição de caridade, perde o referencial clânico e se percebe como mais uma criança a engrossar as estatísticas do abandono. O fragmento ainda apresenta uma crítica aos valores religiosos, à prática do suborno e à violência a que estão submetidos tanto os pais quanto os filhos. 
Nesse novo ambiente, a menina tem contato com histórias de vários jovens em situação semelhante a sua. São crianças que escaparam da morte em praça pública por roubarem alimentos, meninos recrutados para guerrilhas, ou recém-nascidos encontrados no lixo, todas, conforme o texto, "encarnavam os fracassos de seus genitores" que por sua vez, se aglomeravam nos templos cristãos em busca de uma salvação financeira, muito mais do que remissão de pecados.

A partir do ingresso à instituição e ao sequestro, que the sucede, nova rota é realizada pela menina. Vendida como mercadoria de segunda, passa a ser propriedade de membros de uma igreja cristã cujo proselitismo garante o enriquecimento rápido e o sanar de todas as dores "monetárias". Ironicamente denominados de: Vida Eterna, Dom de Deus, Luz Divina e Coluna do Templo, esses dirigentes conciliam as atividades catequéticas oriundas do Ocidente, à permanência de rituais locais e ao tráfico internacional de crianças.

O texto de Miano, nesse ínterim, passa a enfocar a realidade dos aliciamentos de jovens africanos para rede de prostituição internacional e o sonho de muitos deles em "fazerem a Europa", cuja feição de eldorado é ampliada pelo contraste com a realidade de miséria local.

O fragmento a seguir narra a história de Siliki, uma das meninas vendidas ao Luz Divina e que se encontra trancafiada com Musango:

Ela era a única que não dizia nada, mas eu conhecia a sua história. Dom de Deus contara a Kwendi que contou para mim num dia em que estava precisando falar. Siliki gostava de mulher, e um dos seus tios, [...], conseguiu surpreendê-la em suas brincadeiras com a namorada. Siliki precisou confessar sua culpa diante de toda a família. Ficou decidido que não se praticaria a ablação do clitóris, castigo prescrito pela tradição em tais casos. Agora éramos modernos. Os pequenos cortes adiantavam mais que essa mutilação. Então Siliki foi vendida a um traficante de Nasimapula, que a deu ao Luz (MIANO, 2009, p. 44).

O texto denuncia a realidade de muitas crianças que são entregues pelos próprios familiares às redes de prostituição ou, de livre vontade, buscam esses agentes alimentados pelo ideal de fuga da miserabilidade que as oprime.

Pela referência à pedofilia e à prostituição, também o proselitismo religioso ocidental é posto sob rasura, na medida em que é apresentado como um disfarce que encobre todo tipo de violência cometida contra os jovens. Os antigos rituais da sacralidade ancestral são agora "acomodados" à cosmogonia cristã e a hibridação das religiosidades vaticina o destino de 
criaturas que se entendem predestinadas à exploração da qual não buscam escapar.

Após o longo convívio de três anos com essas mercadorias-meninas, Musango procura respostas para sua existência e volta à Sombê para reencontrar a sua mãe, na tentativa de entender seu abandono. Logo, encontra um jeito de fugir do esconderijo e consegue denunciar Luz Divina à polícia. Porém, as autoridades locais não ousam investigar os traficantes sob pena de perderem os benefícios que as igrejas garantem a um sistema embrenhado na corrupção.

Novamente sozinha, Musango decide procurar a escola que frequentara na época em que o pai estava vivo e lá recebe o apoio da diretora. No colégio, descobre que a mãe, atualmente, frequenta uma das muitas igrejas cristãs que infestavam a cidade. Lá, porém, não consegue reencontrá-la. Fracassada mais esta tentativa, dirige-se à casa da avó materna a fim de receber algum apoio na destruída instituição familiar.

Incrustada entre um lixão em Sombê está a residência da avó de $M u$ sango e durante esse percurso, a menina rememora as proibições que a mãe Ihe apresentara em relação à avó, em virtude da pobreza que a distanciava do ideal de enriquecimento orquestrado pela ambição materna. 0 contato com a anciã marca o ingresso de Musango no aconchego familiar, o retorno ao clã, a reconstrução do seu passado, que ao final, possibilitará o seu futuro.

Alimentada pelas histórias da Mbambé, Musango tem notícias de que mãe é acompanhada a distância pela matriarca graças à ajuda de $\mathrm{Mba}$ lé, um jovem rapaz para quem a avó de Musango é uma espécie de mãe adotiva. Musango então acompanha Mbalé ao cemitério e de longe observa a mãe junto ao túmulo do pai. Aproxima-se e não é reconhecida porque três anos se passaram. A mãe Ewenji tenta mais uma vez agredi-la e mostra sinais de insanidade.

Recolhida pelo grupo de jovens amigos de Mbalé, é conduzida à casa de Sessê e Musango retorna com o rapaz para a residência da avó materna. Ambos descobrem que ela está morta e que agora terão que seguir seu caminho por conta própria, fortalecidos pelas lições que o abandono e a errância tatuaram tanto em seus corpos como em suas mentes.

Dessa maneira, a obra de Léonora Miano articula a mensagem de que a afirmação da identidade adolescente em meio às fraturas do póscolonial é algo que demanda luta, reencontros, buscas incessantes, produção. 
As travessias enfrentadas por Musango podem ser lidas como rituais, provas tão comuns às "adolescências" em diversas sociedades e que the impulsionaram ao encontro com um devir identitário mais processo que resultado.

O final do romance é emblemático, porque o sujeito-narrador consegue finalmente libertar-se dos fantasmas da mãe e entender que os sofrimentos proporcionados pela ausência familiar foram subsídios para fortalecer o ser em que se transformara:

Todos esses anos, achei que você não me tivesse dado nada. Não é verdade. Você me deu o que pôde, e isso tem valor. Sem ter consciência, você me indicou o caminho a não seguir, e eu amo ternamente esse saber que herdei de você. Você vê, mamãe, agora é minha vez de viver. Escalei a montanha. Estou agora na outra encosta do desastre, que, ao contrário do que eu pensava, não é a totalidade do laço que nos une. Era apenas uma espécie de abecedário para mim, meu primeiríssimo manual de vida. Ainda vou ler outros (MIANO, 2006, p. 207).

Compreendendo as relações familiares, a convivências com outras instâncias institucionais, o relacionamento interpessoal, os sofrimentos causados pela violência e abandono como instrumentos para produção identitária e para o crescimento pessoal do sujeito-narrador, Miano sinaliza que algumas rotas já foram trilhadas pela jovem Musango, daqui para frente apta a encontrar novos agenciamentos que impelirão a sua identidade a desenvolver inesperadas reterritorializações: a principal delas, anunciada pela união das mãos com jovem Mbalé: "Pego a mão de Mbalé, e é com o coração ardente que seguro "[...] (MIANO, 2009, p. 207).

$\mathrm{O}$ gesto parece sinalizar a esperança de que, em meio aos destroços e incertezas, juntando os esfacelamentos de múltiplas experiências, ambos cresceram e procuram agarrar, juntos, os contornos de uma nova existência como um dia novo que vem vindo

Patrick Chabal (1954) afirma que,

A literatura é uma componente central da identidade cultural de todos os estados-nação, apesar de evidentemente ser muito mais do que isso. Nessa perspectiva, a moderna literatura é melhor entendida historicamente como uma das mais importantes formas de produção cultural, através das quais um estado-nação pode ser identificado (CHABAL, 1994, p. 15).

A literatura moçambicana retratada em $O$ alegre canto da Perdiz (2008), de Paulina Chiziane, a ação colonial alterou de modo emblemático o espaço da aldeia de mãe e filha, Delfina e Maria das Dores, principalmente no que concerne na transformação de suas próprias vidas. As duas se pros- 
tituem em troca de comida. O abandono e a errância em relação à Maria das Dores ocorre principalmente quando é vendida ainda criança, pela própria mãe, ao feiticeiro Simba. O abandono pelo qual passa Maria das Dores representa o símbolo de uma mulher sofrida, oprimida e "decaída" do ponto de vista simbólico, no entanto, apesar desse sofrimento, Maria das Dores também é dotada de sabedoria e determinação e supera muitas contradições.

De acordo com as investigações de Chaves e Macedo (2007),

Nos poucos textos escritos hoje por mulheres nos países africanos de língua portuguesa, o leitor vai poder encontrar os problemas, os sentimentos e a intimidade femininos, abordando desde a marginalização e as tentativas de rebeldia em um mundo de carência [...] até a experiência da solidão e do exílio [...] passando por mulheres que, submetidas a uma tradição que talvez já não corresponda a seu papel na história, revoltam-se e denunciam a opressão, como se vê em obras, da moçambicana Paulina Chiziane.

Maria das Dores, após caminhar solitária por vários anos, à procura de seus três filhos, chega ao rio Licungo, onde toma banho, nua, e desafia os costumes do povo da Vila Gurué. Considerada louca, é apedrejada e amaldiçoada por homens e mulheres da vila. "Ali está a heroína do dia. Protegida na fortaleza do rio. [...] Que venceu um exército de mulheres e colocou desordem na moral pública. Que desafiou os hábitos da terra e conspurcou o santuário dos homens" (CHIZIANE, 2008, p. 16). Maria das Dores é uma mulher estigmatizada, por isso exerce repulsa e desconfiança das pessoas.

Na literatura produzida nas colônias portuguesas na África, o processo de estigma e estereótipo ocorre em relação ao africano: "o peso do estereótipo determina, por conseguinte, que estas personagens mantenham a sua invariabilidade anímica e comportamental na maioria dos textos, tornando-se, por isso, de uma previsibilidade muitas vezes constrangedora". (NOA, 2002, p. 298). Irving Gofman define em seu discurso sobre o estigma de que forma funciona o ser que é estigmatizado, em relação ao indivíduo considerado como normal. Para o autor,

As atitudes que nós, normais, temos com uma pessoa com um estigma, e os atos que empreendemos em relação a ela são bem conhecidos na medida em que são as respostas que a cão social benevolente tenta suavizar e meIhorar. Por definição, é claro, acreditamos que alguém com um estigma não seja completamente humano. Com base nisso, fazemos vários tipos de discriminações, através dos quais efetivamente, e muitas vezes sem pensar, reduzimos suas chances de vida (GOFMAN, 1988, p. 14-15). 
Por esse estigma que carrega, Maria das Dores passa a ser chamada de a louca do rio, e continua perambulando pela cidade sem saber onde encontraria seus filhos: Benedito, Fernando e Rosinha, que foram criados por uma freira, após serem resgatados por militares, no período da guerra colonial, nos montes Namuli, trinta anos atrás. A peregrinação de Maria das Dores assemelha-se a uma penitência, e ser agredida por todos durante a sua caminhada não a faz desistir de encontrar seus filhos:

\begin{abstract}
Como uma condenada a caminhar a vida inteira. Atiraram-lhe pedras por todos os lados onde passou. Expulsaram-na com paus e pedras, como um animal estranho que invadiu propriedades alheias. As vozes queriam que ela desaparecesse. Mas desaparecer para onde se ela não tinha onde ir? Compara as pessoas aos chacais, aos abutres. Não vê diferença. Há uma pessoa no abismo pedindo ajuda. A sociedade humana apressa-se a atirar paus e pedras, a pisar a mão com que te expressas por teu último desejo (CHIZIANE, 2008, p. 13).
\end{abstract}

A mãe de Maria das Dores, Delfina teve a sua sexualidade colocada a serviço do regime salazarista, serviu como prostituta e desejava se relacionar com homens brancos como forma de renegar suas origens e gerar filhos mulatos. Essa era a forma que ela encontrou para sofrer menos preconceitos e ser mais aceita na sociedade. Assim, renega a tradição, mas continua a acreditar em feitiços, além de fazer uso deles. Maria das Dores é exemplo disso: "das palavras, conheço as injúrias, dos gestos as agressões. Tenho o coração quebrado. O silêncio e a solidão me habitam. Eu sou Maria das Dores aquela que ninguém vê" (CHIZIANE, 2008, p. 18).

Maria das Dores causa espanto e indignação a todos os moradores da vila. A "louca do rio" é vítima da ira coletiva, afinal, uma mulher completamente nua na margem de um rio só traz mau agouro. Nesse sentido, a muIher do régulo, que é uma respeitada contadora de histórias, é a única a não se espantar com a imagem daquela mulher misteriosa, e explica a multidão furiosa, que não há mau presságio nenhum, nem anúncio de seca, nem de tormenta no aparecimento da mulher do rio. "A voz da mulher do régulo tinha o poder de serenar multidões. [...] A mulher do rio [...] trazia uma boa nova escrita do avesso" (CHIZIANE, 2008, p. 20).

$A$ visão do povo em relação à mulher nua e o que ela representa foi comentada pela própria Paulina Chiziane. Em entrevista a José Moreira (1999), a moçambicana explica esse temor da figura feminina despida:

Existem vários depoimentos, durante a nossa guerra civil, de batalhões ou pelotões - não sei muito bem - com homens que iam para o combate e 
que levavam à frente uma mulher nua. Isso é uma realidade que qualquer moçambicano pode testemunhar.

Existe o mito de que ver uma mulher nua é o mesmo que ver o diabo. Então, a mulher aparece primeiro, à frente. Imediatamente, desmoraliza o exército inimigo. Porque infelizmente as crenças são muito fortes entre nós. Aconteceu isso várias vezes. Não posso falar muito sobre esses assuntos mas sei dizer que em algumas regiões de Gaza as tropas governamentais simplesmente se acovardaram. Viram aquele azar que era o sinônimo do diabo, e pensaram que a guerra ia correr mal. Por causa disso, aparecia outro exército e derrotava-os. Este é um dos exemplos (MOREIRA, 1999, p. 230).

A mulher do régulo acalma a comunidade, e insere na narrativa uma espécie de reflexão crítica, pois consegue desmistificar através de suas histórias o episódio que parecia "sobrenatural" aos olhos do povo da vila. É por meio de suas narrativas que a mulher do régulo busca retomar ao matriarcado que surge nas narrativas em vários momentos. A contadora de histórias tem total domínio sobre as narrativas do passado e do presente do povo dos montes gelados do Namuli para onde Maria das Dores retorna. Seu propósito é provar ao povo da vila que Maria das Dores não é portadora de mau agouro, pelo contrário ela traz em si a "mensagem da fertilidade", ou seja, ela trazia uma "boa nova escrita do avesso".

Diante dessa perspectiva a autora revela elementos fundamentais da oralidade que são agora apropriados pela escrita. Assim, de acordo com as explanações de Leite, "o romancista africano tende a recuperar simbolicamente a preeminência do narrador que, na tradição oral, recebe o legado e o retransmite, orientando o ato narrativo, com autoridade incontestada pelo seu público, e pelas personagens da sua narrativa" (LEITE, 2000, p. 60).

Para a mulher do Régulo, Maria das Dores trazia a seguinte representação: "Uma mulher nua do lado dos homens? Ó gente, ela veio de um reino antigo para resgatar o nosso poder usurpado. Trazia de novo o sonho da liberdade. Não a deviam ter maltratado e nem expulsado à pedrada"(CHIZIANE, 2008, p. 22). Ou seja, o estigma já estava impregnado em Maria das Dores, mesmo na busca da superação de sua identidade, não era vista como uma igual pelos seus irmãos de raça.

Nesse sentido, para Gofman (1988, p. 118),

Quer mantenha uma aliança íntima com seus iguais ou não, o indivíduo estigmatizado pode mostrar uma ambivalência de identidade quando vê de perto que eles comportam-se de modo estereotipado, exibindo de maneira extravagante ou desprezível os atributos negativos que lhes são imputados. Essa visão pode afastá-lo, já que, apesar de tudo, ele apóia as normas da so- 
ciedade mais ampla, mas a sua identificação social e psicológica com esses transgressores o mantém unido ao que repele, transformando a repulsa em vergonha e, posteriormente, convertendo a própria vergonha em algo de que se sente envergonhado. Em resumo ele não pode nem aceitar o seu grupo nem abandoná-lo.

Delfina, a mãe de Maria das Dores, absorve os problemas dos assimilados, ou seja, no conceito de Albert Memmi (2007), ela teria os complexos do colonizado. Ela decide desprezar a sua raça e renegar todas as instituições, usos e costumes de seu grupo: língua, religião, vestuário, alimentação. Exige que José dos Montes, com quem se casou, seja um assimilado, e ele, com medo de perdê-la, passa a ser sipaio. Armado de escopeta e fardado, José vai se afastando cada vez mais de seu povo e de seus costumes. De Sipaio passa a tuga. Entra para o exército colonial e se destaca como um bom soldado a serviço do salazarismo e do colonialismo.

Esse fato lembra a negação da tradição a favor da modernidade, como ressalta José Luís Cabaço (2009), sobre a política de identidade do movimento de libertação de Moçambique:

Fundava-se numa práxis sócio-política determinada pela adesão à luta contra o colonialismo, que se diferenciava das formas da vida tradicional pelas motivações e pelas novas afinidades que se estabeleciam, promovendo valores e comportamento que permitissem uma apropriação genuína da modernidade, alternativa à intermediação colonial (CABAÇO, 2009, p. 318).

Em uma conversa de Maria das Dores com Delfina, a mãe tenta justificar a filha porque optou por tais parceiros sexuais e de vida:

Sou das que hibernam de dia, para cantar com os morcegos a sinfonia da noite, sou feiticeira. Tive todos os homens do mundo. Dois maridos, muitos amantes, quatro filhos, um prostíbulo e muito dinheiro. O José, teu pai negro, foi a instituição conjugal com que me afirmei aos olhos da sociedade. O Soares, teu padrasto branco, foi a minha instituição financeira. O Simba, esse belo negro, foi minha instituição sexual, o meu outro eu de grandezas imaginárias, que me deixou para ser seu marido (CHIZIANE, 2008, p. 44).

Para Memmi (2007, p. 132), esse comportamento é justificado porque há uma necessidade do colonizado se adequar a um novo espaço, mesmo que seja uma forma de agressão individualizada:

Ao se dirigirem ao conjunto dos colonizados, esses comportamentos, comuns ao conjunto dos colonizadores, se expressarão como instituições. Em outras palavras, eles definem e impõem situações objetivas, que limitam o colonizado, pesam sobre ele, até interferir sobre seu comportamento e imprimir rugas em seu rosto. Em resumo, essas situações serão situações de carências. 
À agressão ideológica que tende a desumanizá-lo e, em seguida, a mistificálo, correspondem em suma situações concretas que visam ao mesmo resultado.

A mudança de José faz parte do sonho de Delfina, no entanto ela deseja é casar-se com um branco, levar a vida de mulher branca, e assim poder ser respeitada por todos. Na definição de Franz Fanon, esse pensamento da descolonização, infiltrando-se no universo do colonizador, faz com que o indivíduo vista a máscara do outro para poder adaptar-se ou ser aceito em seu mundo.

Na análise de Fanon (2008), no capítulo "A mulher de cor e o branco", ele explica:

Compreendemos agora porque o negro não pode se satisfazer no seu isolamento. Para ele só existe uma porta de saída, que dá no mundo branco. Donde a preocupação permanente em atrair a atenção do branco, esse desejo de ser poderoso como o branco, essa vontade determinada de adquirir as propriedades de revestimento, isto é, parte do ser e do ter que entra na constituição de um ego. É pelo seu interior que o negro vai tentar alcançar o santuário branco. A atitude revela a intenção (FANON, 2008, p. 60).

Delfina busca o fim da miséria em que vive, porém não conta com o abandono do homem conquistado. Ela não consegue manter o seu relacionamento por muito tempo com o português Soares, que era um colonizador preocupado com o colonizado. Soares era um português atípico, diferente dos outros, as suas reflexões eram manifestadas por preocupações políticas e sociais. Dessa forma, quando Soares percebe que a simplicidade e que lembrava os valores que ele não via mais em Delfina, resolveu abandoná-la, deixando-a sozinha e amargurada. Eis o pensamento de José de Montes em relação à Maria das Dores e ao seu relacionamento:

Não, não era ela a culpada de tudo. Foi gerada no berço de um tormento. Aprendeu a vida na moral das ruas. Produz alimento nas minas do sexo, a fidelidade e a infidelidade são peças da mesma sorte. Não, não pode ser incriminada. Ela é demasiado generosa no amor que tem para dar e para vender. Delfina dos contrastes, dos conflitos, das confusões e contradições. Não podia ser ela a causa do tormento. Talvez Deus e o destino. Talvez o próprio José dos Montes, que desenhou fantasias sobre o amor e fez do corpo dela barco e âncora, sem porto seguro (CHIZIANE, 2008, p. 166).

Outro aspecto observado no romance é o fato de que Delfina quando rica reforça em muito a sua intolerância racial, radicalizando o seu comportamento de assimilada. Ela discrimina os próprios filhos negros, Maria das Dores e Zezinho, que são filhos de José dos Montes. Nesse caso, eles fazem 
o serviço da casa, e são responsáveis pela organização do lar, sendo negado a ambos direito à educação. Com essa atitude, Delfina acaba adquirindo uma rejeição pelo próprio negro.

A partir dessa reflexão, Fanon explica que

o problema é saber se é possível ao negro superar seu sentimento de inferioridade, expulsar de sua vida o caráter compulsivo, tão semelhante ao comportamento fóbico. No negro existe uma exacerbação efetiva, uma raiva em se sentir pequeno, uma incapacidade de qualquer comunhão que o confina em um isolamento intolerável (FANON, 2008, p. 59).

No entanto, os dois filhos mulatos, oriundos do relacionamento com Soares, são tratados todos com distinção, estudam, e não precisam realizar trabalhos domésticos. Nesse sentido, a forma que José dos Montes fez para ser assimilado, foi a saída encontrada para ser aceito por uma sociedade conservadora e tradicional, como pode ser observado a seguir:

Quem não se ajoelha perante o poder do império não poderá ascender ao estatuto de cidadão. Se não conhece as palavras da nova fala jamais se poderá afirmar. Vamos, jura por tudo que não dirá mais uma palavra nessa língua bárbara. Jura, renuncia, mata tudo, para nasceres outra vez. Mata a tua língua, a tua tribo, a tua crença. Vamos, queima os teus amuletos, os velhos altares e os velhos espíritos pagãos (CHIZIANE, 2008, p, 117).

José dos Montes necessitou da assimilação, estava cansado de ser colonizado, por isso cedeu aos apelos de Delfina: "Colonizar é fechar todas as portas e deixar apenas uma. A assimilação era o único caminho para a sobrevivência" (CHIZIANE, 2008, p. 117). José dos Montes sabia do poder da assimilação, e nessa passagem ocorre mais uma vez o abandono a tudo o que ele conhece, mas aceita ser um novo assimilado, acreditando ser aceito por uma nova sociedade que vigia e pune.

Para Bhabha (1998, p. 214),

em Vigiar e punir, de Foucault, aprendemos que os mais individuados são aqueles sujeitos colocados às margens do social, de modo que a tensão entre a lei e a ordem pode produzir a sociedade disciplinadora ou pastoral. Tendo colocado o povo nos limites da narrativa da nação, quero agora explorar formas de identidade cultural e solidariedade política que emergem das temporalidades disjuntivas da cultura nacional. Essa é uma lição da história a ser aprendida com aqueles povos cujas histórias de marginalidade estão enredadas de forma mais profunda nas antinomias da lei e da ordem - os colonizados e as mulheres.

Notamos o fato de que ao destituir o colonizado do seu caráter de sujeito, o colonizador busca sua imposição como o humano-humanizador, 
seria o contraponto da não civilidade. Dessa forma, Fanon (2005) afirma que ao colonialismo não basta encerrar o povo em suas malhas, esvaziar seus cérebros de toda forma e todo conteúdo. Por uma espécie de perversão lógica, ele se orienta para o passado do povo oprimido, deforma-o, desfigura-o, aniquila-o. É evidente, como afirma Frantz Fanon, que o processo colonial não pode pressupor um nível de igualdade entre colonizado e colonizador. Ao contrário, a lógica colonial implica o desconhecimento da humanidade do colonizado e, assim, atribui-lhe a condição de objeto.

Quando Delfina é abandonada por Soares, a sua vida volta a ser a de miséria e penúria, e por conta dessa situação, ela toma duas decisões desastrosas: primeiro, abre um prostíbulo e passa a explorar a sexualidade infantil, em seguida, vende a virgindade da própria filha, Maria das Dores, que na época estava com treze anos de idade, ao feiticeiro Simba. Notamos o fato dessa vivência que ocorre entre mãe e filha são típicas de uma sociedade que ainda submete-se ao regime patriarcal.

Manuel Castells explica como essa caracterização se concretiza:

[...] pela autoridade, imposta institucionalmente, do homem sobre mulher e filhos no âmbito familiar. Para que essa autoridade possa ser exercida, é necessário que o patriarcalismo permeie toda a organização da sociedade, da produção e do consumo à política, à legislação e à cultura. Os relacionamentos interpessoais e, conseqüentemente, a personalidade, também são marcados pela dominação e violência que têm sua origem na cultura e instituições do patriarcalismo (CASTELLS, 2001, p. 169).

Sem o julgo do método patriarcal o sentimento de abandono pelo qual passará Maria das Dores, faz com que ela se fortaleça, mas o tempo passa, ela é mãe de três filhos, assim decide fugir da casa do feiticeiro, levando os filhos. Após essa fuga, os filhos são resgatados nos montes Namuli e criados por uma freira. Quando Delfina perde todos os filhos, ela começa a pensar em seus atos. Maria Jacinta, a filha mulata, a ataca frontalmente no dia de seu casamento. Quando abandona Simba, seu senhor e opressor, caminha errante pelas aldeias de Moçambique, durante a guerra e chega aos Montes Namuli, momento emblemático do romance, uma vez que simboliza o local de nascimento da humanidade, principalmente referente ao universo feminino.

Para Tânia Macêdo, há um confronto entre tradição e modernidade na ficção de Paulina Chiziane, mesmo que a personagem feminina passe por determinadas contradições:

Nos textos de Paulina Chiziane encontramos o universo do interior de Moçambique. Tais textos constituem um mergulho em costumes, lendas e pers216 Número temático: Literatura, cultura e memória negra. A Cor das Letras - UEFS, n. 12, 2011 
pectivas de populações distantes do litoral, o que, segundo entendemos, permite destacar uma das linhas de força de sua escrita: a evocação da tradição - seja dos ritos e crenças, seja das maneiras de contar - como força propulsora para uma modernidade do relato, fazendo com que memória e tempo presente, ancestralidade e modernidade confluam em uma narrativa bastante densa (MACÊDO, 2003, p. 155).

Diante desse contexto, durante a sua vida, Delfina realizou vários tipos de atrocidades. A falta de honradez, moralidade e piedade foram elementos essenciais para a destruição da vida de José dos Montes e a do Português Soares, que já tinha uma família constituída. Ela repete com a filha Maria das Dores, o que a mãe fizera com ela, que também foi vendida em troca de alimento. Delfina foi prostituta do cais, expulsa da igreja, principalmente por provocar nos padres idéias voluptuosas. No relacionamento com homens brancos e negros, teve filhos negros e mulatos, quase brancos. Ela desejava se livrar desse estigma. "Por isso a mulher negra buscará um filho mulato. Para aliviar o negro da sua pele como quem alivia as roupas de luto" (CHIZIANE, 2008, p. 184):

Os filhos negros representam um mundo antigo. O conhecido. São o meu passado e o meu presente. Sou eu. E eu já não quero ser eu. Os filhos mulatos são o fascínio pelo novo. Instrumentos para abrir as portas do mundo. A Zambézia ainda é virgem, não tem raça. Por isso é preciso criar seres humanos à altura das necessidades do momento (CHIZIANE, 2008, p. 230).

Nesse contexto, quando afirma que a Zambézia ainda é virgem, não tem raça, e entender que é necessário criar seres humanos à altura das necessidades do lugar, compreendemos porque Delfina e Maria das Dores representam a própria Zambézia, lugar que simboliza a África colonizada e assimilada pelo homem europeu. No entanto, também é o retrato da resistência, representado pelos montes Namuli, e pelas histórias da mulher do Régulo, a contadora de histórias que mostra nas narrativas o poder do mundo matriarcal.

A voz dos m'zambezi se ouvia mais alto. Lutando desesperados pela Zambézia amada, pátria de palmeiras altas, semeadas pelas mãos dos escravos como testemunhos da história. Defendem o Zambeze, seu rio, onde os peixes saborosos brincam como nenúfares florindo nas ondas. Apesar do sofrimento - dizem no canto - é bom nascer na Zambézia. O chão é de mármore, ouro e madrepérola, é bom viver na Zambézia. A relva é de verde-vivo e os montes cobertos de antúrios. A terra inteira é uma laje fl orida, que convida ao repouso eterno. É bom morrer na Zambézia (CHIZIANE, 2008, p. 129). 
O alegre canto da perdiz é uma reflexão a respeito dos traumas da colonização, da escravidão e das guerras, no paradoxo entre tradição e modernidade, os mitos do passado, e as intervenções do presente. A união da família é o trunfo utilizado pela autora com o intuito de mostrar que o mundo africano faz sentido pelo círculo familiar, principalmente quando o romance destaca em seu enredo, os filhos e José dos Montes reconciliamse com Delfina. A reconciliação entre Maria das Dores e Simba torna-se possível, este encontra o padre, seu filho, nos montes Namuli, local simbólico que transforma-se em retorno para todos. No entanto, Delfina é consciente sobre a representação do colonialismo na vida de todos:

O colonialismo incubou e cresceu vigorosamente. Invadiu os espaços mais secretos e corrói todos os alicerces. Já não precisa de chicote nem da espada, e hoje se veste de cruz e silêncio. Impregnou-se na pele e nos cabelos das mulheres, assíduas procuradoras da clareza epidérmica, na imitação de uma raça. As bocas das mães negras expelem raivas contra o destino e perdem a melhor energia na fútil reprodução de um deus perfeito. Trinta anos de independência e as coisas voltam para trás. Os filhos dos assimilados ressurgem violentos e ostentam ao mundo o orgulho da sua casta. O colonialismo já não é estrangeiro, tornou-se negro, mudou de sexo e tornou-se mulher. Vive no útero das mulheres, nas trompas das mulheres e o sexo delas se transformou em ratoeira para o homem branco (CHIZIANE, 2008, p. 332-33).

As personagens femininas em $O$ alegre canto da perdiz suportam a dor do preconceito de gênero e de raça em razão dos processos opressores de dominação colonial, mas também são conscientes de que os assimilados remeteram seu povo ao sofrimento, e é com esse sentimento que Delfina compreende a dura representação do colonialismo. Esse processo de escrita-testemunho, que Paulina Chiziane concretiza em narrativa, destaca o pensamento de Inocência Mata sobre tal fato representar o modo de pesar africano:

As literaturas africanas, metonímias do percurso histórico dos países históricos parecem hoje coincidir é no percurso da sua existência enquanto "textosmemória" da História dos países. No seu período de emergência e consolidação do sistema literário em que as literaturas, em que a literatura funcionou como subsidiária da informação nacional e identitária face à ideologia colonial, essas literaturas fizeram-se, grosso modo, "relatos de nação em devir". Nesta marcha, o discurso prevalecente era aquele que buscava sintetizar as diferentes vozes (afinal, as diferentes visões sobre o processo de formação anticolonial) partilhar memórias históricas e forjadas, e coletivizar angústias e aspirações (MATA, 2008, p. 81). 
Na ficção de Leonora Miano, o abandono e a errância acompanha a vida da menina Musango. Traumatizada com a guerra que destruiu Mboasu, um país africano imaginário, as crianças ficam sem seus pais, que não podem mais cuidar de seus filhos. Por mais cruel que a narrativa se apresenta, os filhos são expulsos de casa, além de serem penalizados por serem a causa de todos os as desgraças da família. Nesse contexto, Musango, que é uma das meninas acusadas pelo infortúnio, está decidida a reencontrar sua mãe para tentar entender a sua própria história.

O relato dessa narrativa é em grande parte realizada em forma de monólogo, e nessa caminhada da personagem, observa-se o desespero do abandono, a angústia por não encontrar sua mãe, além de perceber o desenvolvimento de uma criança totalmente desolada em um país devastado pela violência, prostituição e as mistificações religiosas. No monólogo, Musango observa a complexidade da África, a diversidade de seu povo e a vida repleta de paradoxos e injustiças, no entanto não perde a esperança de encontrar dias melhores. Na mesma linha de pensamento, em $O$ alegre canto da perdiz, de Paulina Chiziane, há no decorrer da narrativa uma comunicação entre diferentes realidades, que são materializadas na experiência de várias gerações, envolvendo avó, mãe e filha. Inicialmente o romance destaca a história de Maria das Dores, uma mulher misteriosa que aparece completamente nua em pleno rio Licungo. Esta mulher representa a metáfora da identidade feminina e moçambicana, uma vez que além de causar revolta na população, assusta as mulheres com sua nudez.

No desenrolar da narrativa, é nítido o processo de discriminação racial e de gênero, promovendo uma reflexão sobre a história do papel matriarcal africano, e a condição da mulher, envolvendo etnias e poder econômico ou social. Este jogo de conceitos transforma o romance $O$ alegre canto da perdiz, em um conflito racial inerente à construção no modo de compreender a "identidade moçambicana", como resultado dos processos históricos das realidades colonial e pós-colonial.

Nesse sentido, as duas obras analisadas mostram os aspectos de abandono em uma perspectiva que focaliza a mulher enquanto sujeito e objeto, no seio do complexo cenário pós-colonial africano. A escritora camaronesa Léonora Miano em sua narrativa, assim como a moçambicana Paulina Chiziane atribuem à guerra uma espécie de dicção feminina, uma vez que em ambos escritos é a mulher quem retrata a realidade caótica e cruel da sociedade que convive com a atrocidade e a ruína, seja do ponto 
de vista de uma criança, no primeiro romance, a uma visão madura e reflexiva de uma adulta no segundo romance.

Segundo Venâncio, ao abordar a temática do poder na literatura africana, o pensamento coaduna-se ao que foi desenvolvido nas narrativas das duas escritoras africanas:

Mesmo que a temática do poder não esgote naturalmente as literaturas francófona e anglófona do pós-independência, ela não deixa de ser dominante. Este fato, aliado a um aspecto messiânico que, por vezes, os seus textos tomam e ainda à característica de a ficção ser geralmente construída sobre um fundo histórico, verdadeiro (coexistindo como que duas histórias paralelas, sendo uma ficção e a outra realidade), levou a que os críticos literários e africanólogos tivessem visto aí um particularismo estilístico que passaram a designar de realismo africano. É assim que para Mohamadou Kane, um conhecido especialista destas matérias afirma que o romance [africano] funciona como o espelho de uma sociedade e o investimento de uma missão terapêutica dupla. Por um lado, ele fixa-se à pintura objetiva das realidades africanas, das tensões, conflitos e postulações, forjando uma nova imagem de África e do Negro; por outro lado, ele empenha-se em tirar este último da sua apatia, de uma certa resignação, para o inserir numa corrente de modernização (VENÂNCIO, 1992, p. 9).

A partir desse contexto, os dois romances trazem o desconforto do abandono e a busca de uma identidade como possibilidades na capacidade de ambas as escritoras lerem os contextos históricos, sociais e culturais, que acompanharam o crescimento de seus países, acusando em suas narrativas, os muitos sofrimentos intrínsecos. O escritor moçambicano Mia Couto acredita na seguinte afirmação: "os africanos estão nesta situação de fronteira: ao aceitarem a sua identidade como sendo múltipla, mestiça e dinâmica eles tem a possibilidade de se reinventarem e não se perderem em ilusórias viagens à "essência" de sua identidade" (COUTO, 2005, p. 80).

\section{REFERÊNCIAS}

APPIAH, Anthony Kwame. Na casa do meu pai: África na filosofia cultural. Rio de Janeiro: Contraponto, 1997.

BHABHA, Homi K. O local da cultura. Trad. Miriam Ávila, Eliana Lourenço de Lima Reis, Gláucia Renate Gonçalves. Belo Horizonte: Ed. UFMG, 1998.

CABAÇO, José Luís. Moçambique: identidade, colonialismo e libertação. São Paulo: Ed. UNESP, 2009.

CASTELLS, Manuel. O poder da identidade. 3. ed. Trad. Klauss Brandini Gerhardt. São Paulo: Paz e Terra, 2001, v. 2. 
CHABAL, Patrick. Vozes moçambicanas: literatura e nacionalidade. Lisboa: Veja, 1994.

CHAVES, Rita. Angola e Moçambique: experiência colonial e territórios literários. São Paulo: Ateliê, 2005.

CHAVES, Rita; MACEDO, Tânia. Caminhos da ficção da África portuguesa. In: Idem. Vozes da África - biblioteca entre livros. Editora Duetto, edição especial n. 6, 2007.

CHIZIANE, Paulina. O alegre canto da perdiz. Lisboa: Caminho, 2008.

COUTO, Mia. Pensatempos: textos de opinião. Lisboa: Caminho, 2005.

DAHLBERG, G.; MOSS, P.; PENCE, A. Qualidade na educação da primeira infância: perspectivas pós-modernas. Porto Alegre: Artmed, 2003.

FANON, Frantz. Os condenados da terra. 2. ed. Prefácio de Jean-Paul Sartre; Prefácio de Alice Cherri; Prefácio de Mohammed Harbi. Trad. Enilce Albergaria Rocha, Lucy Magalhães. Juiz de Fora: UFJF, 2005.

FANON, Frantz. Pele negra máscaras brancas. Trad. Renato da Silveira, Salvador: EDUFBA, 2008.

GLISSANT, Édouard. Introducción a uma poética de lo diverso. Barcelona: Ediciones del Bronce, 2002.

GLISSANT, Édouard. O mesmo e o diverso. Trad. Normélia Parise. In: Idem. Le discours antillais. Paris: Seuills, 1981, p. 190-201.

GUATTARI, Félix. Caosmose: um novo paradigma estético. Rio de Janeiro: Ed. 34, 1992.

GUATTARI, Félix; ROLNIK, Suely. Micropolítica: cartografias do desejo. Petrópolis: Vozes, 2005.

GUATTARI, Félix. Mil Platôs: capitalismo e esquizofrenia, v. 1. Rio de Janeiro: Ed. 34, 1995.

GOFMAN, Erving. Estigma: notas sobre a manipulação da identidade deteriorada. Rio de Janeiro: LTC, 1988.

HALL, Stuart. Da diáspora: identidades e mediações culturais. Belo Horizonte: UFMG, 2003.

HALL, Stuart. A identidade cultural na pós-modernidade. Trad. Tomás Tadeu da Silva e Guacira Louro. Rio de Janeiro: DP\&A, 2002.

LEITE, Ana Mafalda. Literaturas africanas e formulações pós-coloniais. Lisboa: Edições Colibri, 2000.

MACÊDO. Tânia. Estas mulheres cheias de prosa: a narrativa feminina na África de língua oficial portuguesa. In: LEÃO, Angela Vaz. (Org.). Contatos e ressonâncias: literaturas africanas de língua portuguesa. Belo Horizonte: PUC Minas, 2003.

MATA, Inocência. Paulina Chiziane: uma coletora de memórias imaginadas. In: Idem. Metamorfoses. Lisboa/Rio de Janeiro: Cosmos/Cátedra Jorge de Sena, 2000.

MATA, Inocência. "Laços de memória": a escrita-testemunho como terapêutica na literatura africana - os casos de Angola e Costa do Marfim. In: SILVA, Agnaldo Rodrigues da. Diálogos literários: literatura, comparativismo e ensino. São Paulo: Ateliê, 2008.

MATTOS, Regiane Augusto. História e cultura afro-brasileira. São Paulo: Contexto, 2009.

MEMMI, Albert. Retrato do colonizado precedido pelo retrato do colonizador. Rio de Janeiro: Paz e Terra, 2007. 
MIANO, Léonora. Contornos do dia que vem vindo. Rio de Janeiro: Pallas, 2009.

MOREIRA, José. Entrevista Paulina Chiziane. "Escrevo estas coisas e fico arrepiada". Uma escritora de Moçambique que enfrentou e enfrenta várias guerras. Expresso. Lisboa, dez 1999.

NOA, Francisco. Império, mito e miopia. Moçambique como invenção literária. Lisboa: Editorial Caminho, 2002.

PERRACHO, Bianca Basile; FORLI, Cristina Arena. Venenos de Deus, remédios do diabo: a solidão no compasso da pós-independência de Moçambique. Revista Historiador, ano 3, n. 3, 2010. Disponível em: http://www.historialivre.com/revistahistoriador. Acesso em: 10 ago. 2011.

SANTOS, Luís Alberto Ferreira Brandão; OLIVEIRA, Silvana Pessoa de. Sujeito, tempo e espaços ficcionais: introdução à teoria da literatura. São Paulo: Martins Fontes, 2001.

SERRANO, Carlos; WALDMAN, Maurício. Memórias da África. São Paulo: Cortez, 2007.

VENÂNCIO, José Carlos. Literatura e poder na África lusófona. Lisboa: Ministério da Educação: Instituto de Cultura e Língua Portuguesa, 1992. 